\title{
Behaviour of Sepiolite, Vermiculite and Montmorillonite as Supports in Anaerobic Digesters
}

\author{
J.L. PÉREZ RODRÍGUEZ , M.I. CARRETERO and C. MAQUEDA \\ Instituto de Ciencia de Materiales, C.S.I.C., 41080 Sevilla (Spain) \\ Instituto de Recursos Naturales y Agrobiología de Sevilla, C.S.I.C. Apartado 1052, 41080 \\ Sevilla (Spain)
}

The effect of some clay minerals as support for methane production by an anaerobic process was studied. The clay minerals used were: natural sepiolite, treated sepiolite (both from Vallecas, Spain), vermiculite from Santa Olalla (Spain) and montmorillonite from Gador (Spain). Expanded polyurethane and PVC were also used in order to compare these materials, frequently used as supports in anaerobic digesters, and clay minerals.

Treated sepiolite in suspension is the material that produces more methanobacteria. This is the only mineral able to fix the bacteria when it is in suspension. The best results for sedimentation are also obtained with this material.

Magnesium released from the supports may play an important role in anaerobic digestion.

\section{INTRODUCTION}

One of the most important problems in anaerobic processes is the loss of biomass. In order to solve this problem, reactors have been designed containing supports, which fix the biomass and result in high loading densities and small hydraulic retention times (Henze and Harremöes, 1983). With the increase of population density on the given support, there is an enhanced opportunity for cross-feeding, co-metabolism, and interspecies hydrogen and proton transfer, which may further stimulate the growth of microcolonies (Slater, 1978; Ellwood et al., 1982).

Expanded polyurethane (Huysman et al., 1983), glass beads, volcanic rocks (Salkinoja-Salonen et al., 1983), needle-punched polyester (Harvey et al., 1984 ), feldspar particles (Lequerica and Toldrá, 1986), polyvinyl chloride (Van 
der Berg and Kennedy, 1981; Murray and Van der Berg, 1981) are the most frequently used supports in anaerobic digesters.

Clay minerals have a high specific surface area and the property of sorbing certain anions and cations and retaining them in an exchangeable state; also organic compounds can be adsorbed on clay minerals. For these reasons they may play an important role in anaerobic processes.

Murray and Van der Berg (1981) used clay (fired at $1050^{\circ} \mathrm{C}$ ) as support. Growth tests in the presence and absence of suspended clay particles and clay extracts showed that clay contained and released nutrients beneficial in stimulating methanogenic activity. Similarly, methanogenesis was stimulated in the presence of fired-clay particles.

Hattori and Hattori (1976) found that the cation exchange capability of clays provided a slow release of nutrients to attached bacteria. Iron and possibly other elements added in solution are readily precipitated and become unavailable (Hoban and Van der Berg, 1979). The slow release of elements from clays would be very beneficial to the slow-growing acetate-convertingmethanogens once they become attached.

Huysman et al. (1983) have used sepiolite as support. They found that the colonization was faster for sepiolite than for other supports. This behaviour was attributed to the existence of crevices in the sepiolite surface of a size similar to that of the bacteria. Electron micrographs showed that the biofilm attached to the surface mainly consisted of methanosarcina.

Geeta et al. (1986) have used vermiculite powder as support in biogas production from bovine excreta, and found that this mineral increases biogas generation. They suggested that the surface of vermiculite seems to serve a function in increasing the metabolism and methane production. They also found that the time necessary for starting gas production is sensibly reduced. Stotzky (1966) and Stotzky and Rem (1966) reported that vermiculite stimulated respiration and served as a mineral source in bacterial cultures. Schoberth (1979) observed that methane production was increased in the presence of vermiculite.

The principal group of bacteria acting in anaerobic digestion processes are those responsible for methane production. These methanogenic bacteria grow more slowly than others involved in anaerobic processes (Henze and Harremöes, 1983).

The aim of this paper is to study the effect of some clay minerals on anaerobic digestion by comparing them with commonly used supports such as expanded polyurethane or polyvinyl chloride.

\section{EXPERIMENTAL}

\section{Materials}

Clay minerals. (1) Treated sepiolite from Vallecas (Spain). Industrially treated in order to get a better dispersion of the material, being also enriched in its 
sepiolite content. Supplied by TOLSA, S.A. The material was supplied as rings of $3 \mathrm{~cm}$ diameter.

(2) Natural sepiolite from Vallecas (Spain). Supplied in the same way as the preceding material.

(3) Vermiculite from Santa Olalla deposit in Huelva (Spain).

(4) Montmorillonite from bentonite of Gador (Spain). Supplied by Minas de Gador. The material was compressed to form cylinders of 1.6 to $2.0 \mathrm{~mm}$ diameter, which were dried at $300^{\circ} \mathrm{C}$.

Organic polymers. (1) Expanded polyurethane. (2) Polyvinyl chloride (PVC). These substances were chosen as comparative support.

All the materials were cut or broken into pieces of about $1.6-2.0 \mathrm{~mm}$ diameter.

\section{Methods}

Seven 1-1 reactors were used. The reactors were filled with $100 \mathrm{~cm}^{3}$ of supports and provided with magnetic stirrers. A blank support-free reactor was prepared for comparison. These digesters were inoculated by biomass from an anaerobic reactor that processes waste water of a piggery. Synthetic cultures were added every day for the development of methanobacteria (Huysman et al., 1983).

These reactors were kept at a constant temperature of $35^{\circ} \mathrm{C}$ in a water bath. They were provided with an outlet leading to a water container. The gas production was measured by the displacement of water and was recorded every day for 3 months.

Before and after the process of digestion all the mineral supports were studied by the following methods.

(1) Thermal analysis (DTA, TG) in ta Rigaku instrument, model PTC$10 \mathrm{~A}$.

(2) Scanning electron microscopy (SEM) in an ISI apparatus, model SS40, and the dispersion energy of $\mathrm{X}$-rays was measured by a Kevex analyser, model 8000. The observed bacteria were fixed in osmium tetraoxide and glutaraldehyde in buffer solutions of sodium cacodilate followed by dehydration with acetone-water solutions of different concentrations.

(3) X-ray diffraction (XRD) in a Siemen diffractometer, model Kristaloflex D-500 using $\mathrm{Ni}$-filtered $\mathrm{CuK} \alpha$ radiation.

(4) Chemical analysis. The determination of elements was made following the method proposed for the dissolution of silicates by Bennet et al. (1962), with the concentration of the elements being determined by atomic absorption spectrometry (Perkin-Elmer model 703).

The CEC of the clays were determined by exchange with ammonium acetate at $\mathrm{pH} 7$ and the nonmineral supports were only studied by scanning electron microscopy.

When stirring of the contents of the reactors was stopped, the coarse parti- 
cles of the supports settled and the fine fractions remained in suspension. Both phases were studied to detect the influence of the support on bacteria growth.

\section{RESULTS}

The blank and loaded digesters were fed with a synthetic medium for increasing the development of methanobacteria. Samples of the suspension and of the settled solid from each reactor were studied by the methods described above.

Blank digester

In this reactor struvite $\left(\mathrm{MgNH}_{4} \mathrm{PO}_{4} \cdot 6 \mathrm{H}_{2} \mathrm{O}\right)$ was formed in suspension, as shown by the X-ray diagram (Fig. 1). The different phosphate compounds precipitated in digesters were studied in a previous paper (Carretero et al., 1986).

Electron micrographs indicated the presence of bacteria (Methanosarcina and some bacilli) but in smaller quantities than in the digesters loaded with supports. Struvite was also detected.

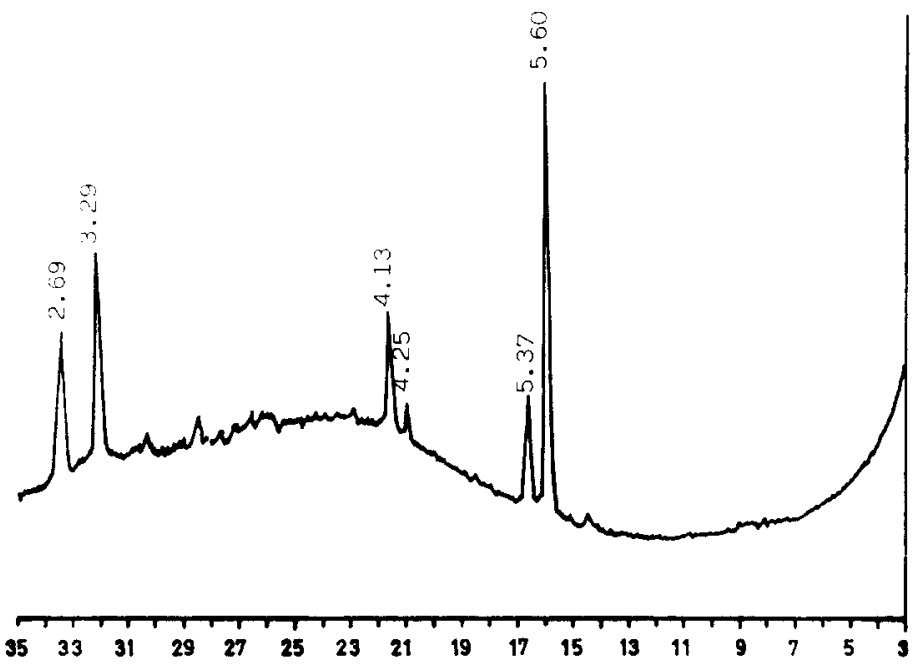

$2 \theta$

Fig. 1. X-ray diffraction pattern of the final suspension of the blank digester showing the presence of struvite. 

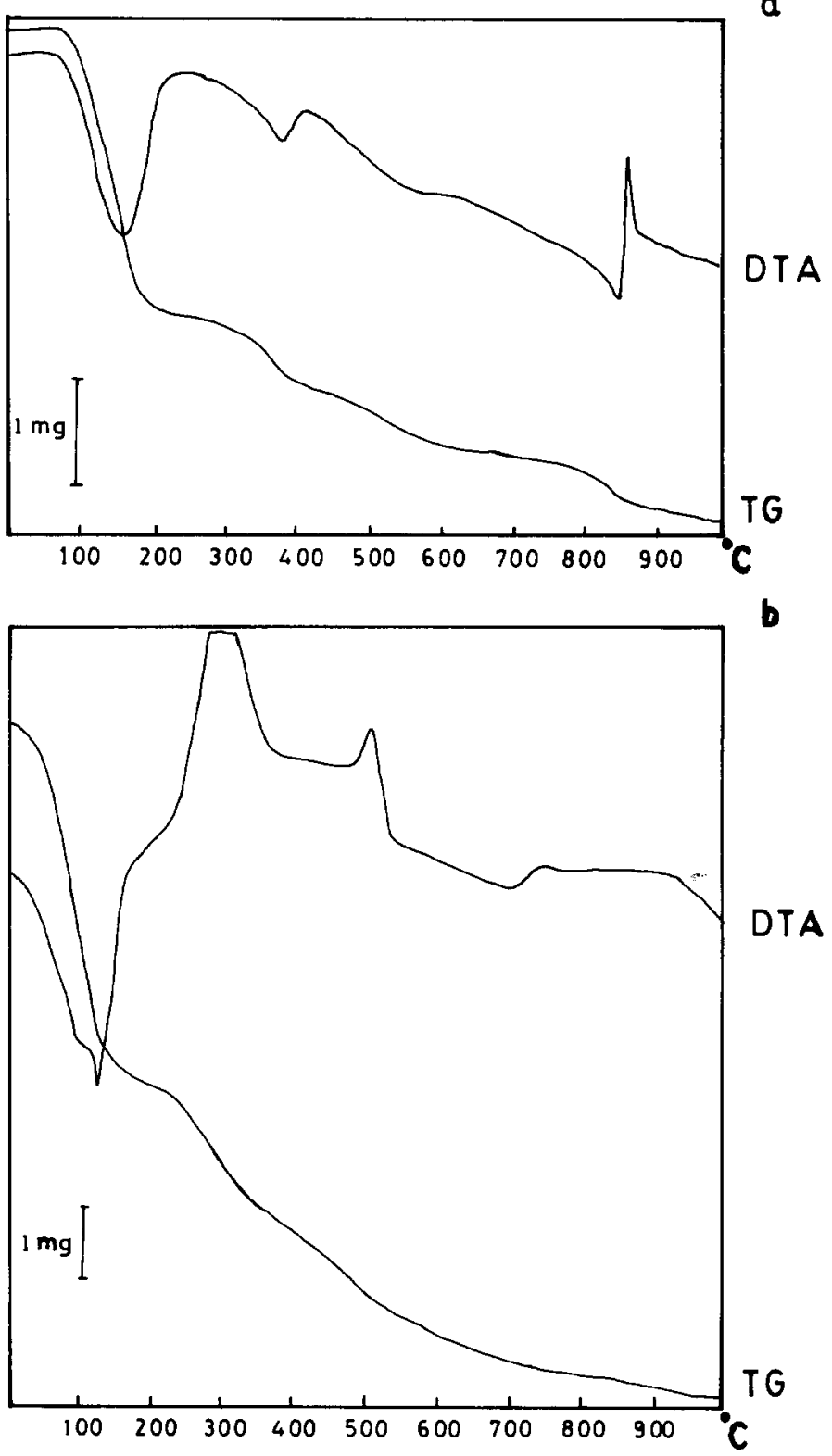

Fig. 2. Gravimetric and differential thermal analysis curves of treated sepiolite: a) before treatment; b) after the anaerobic process.

\section{Treated-sepiolite digester}

The XRD pattern of the suspension sample not presented here showed that it consisted of sepiolite and struvite. The gravimetric and differential thermal 


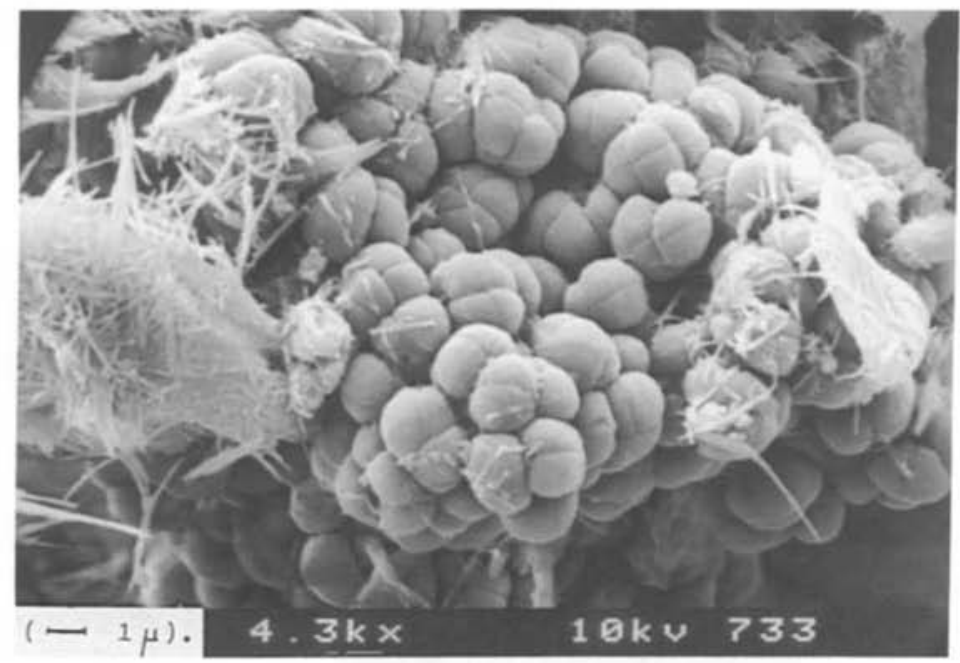

Fig. 3. Scanning electron micrograph of the material in suspension, after the anaerobic process, from the reactor using treated sepiolite as support (Methanosarcina and the mineral).

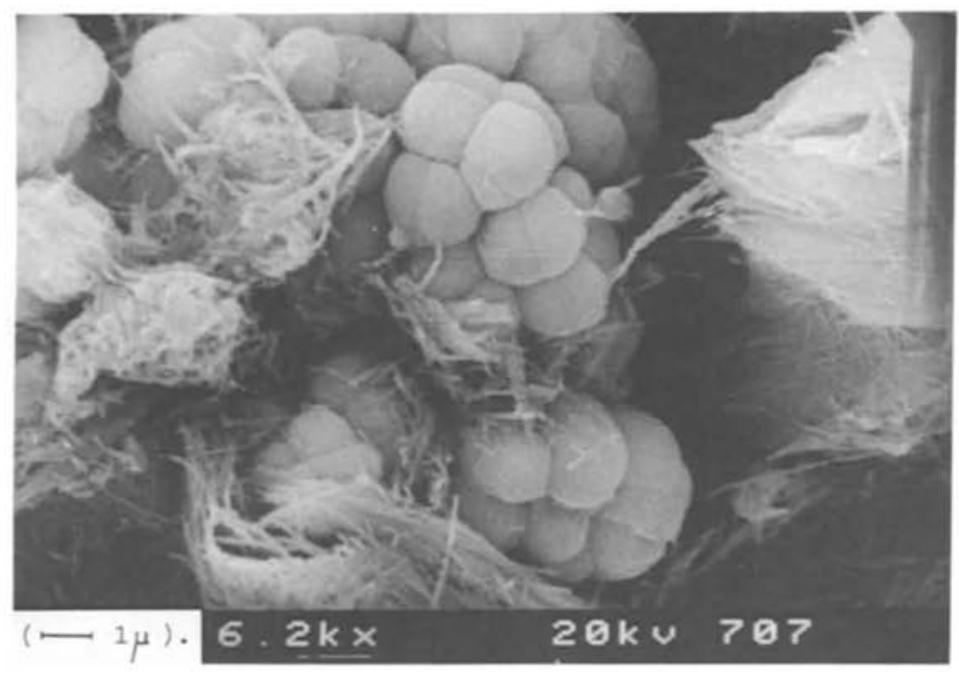

Fig. 4. Scanning electron micrograph of the material in suspension, after the anaerobic process, from the reactor using treated sepiolite as support (Methanosarcina and the mineral).

analysis curves of treated sepiolite (Fig. 2) show endothermic and exothermic effects and weight loss characteristic of this mineral. The corresponding curves for sepiolite after the anaerobic digestion show exothermic effects at 300 and $500^{\circ} \mathrm{C}$ attributed to the organic matter present. Endothermic effects about $100^{\circ} \mathrm{C}$ due to dehydration of salts, organic matter and the clay mineral also appear. The other effects corresponding to sepiolite are not present, due to the 


\section{TABLE I}

Chemical analysis of original vermiculite (figures refer to pecentage of the total mass of sample dried at $110^{\circ} \mathrm{C}$ )

\begin{tabular}{lrlr}
\hline $\mathrm{SiO}_{2}$ & 36.93 & $\mathrm{CoO}$ & 0.00 \\
$\mathrm{Al}_{2} \mathrm{O}_{3}$ & 18.01 & $\mathrm{CuO}$ & 0.01 \\
$\mathrm{Fe}_{2} \mathrm{O}_{3}$ & 4.62 & $\mathrm{Na}_{2} \mathrm{O}$ & 0.30 \\
$\mathrm{TiO}_{2}$ & 0.32 & $\mathrm{~K}_{2} \mathrm{O}$ & 0.16 \\
$\mathrm{CaO}$ & 0.39 & $\mathrm{MnO}$ & 0.16 \\
$\mathrm{MgO}$ & 28.01 & $\mathrm{ZnO}$ & 0.01 \\
$\mathrm{NiO}$ & 0.01 & Ign. loss & 10.67 \\
\hline
\end{tabular}

Exchangeable magnesium (\% $\mathrm{MgO}) 2.80$

C.E.C. (meq. $/ 100 \mathrm{~g}) 140.00$.

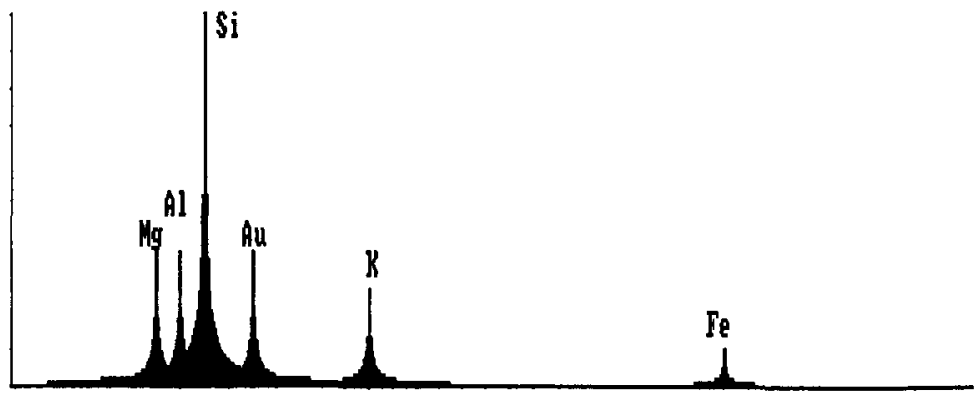

Fig. 5. Chemical analysis of vermiculite by EDX after the anaerobic process.

scale used in the figure and these effects were overlapped by the other components present in the mixture.

The concentration of methanobacteria (Methanosarcina) in suspension observed by electron microscopy was the highest as compared with other supports. The bacteria in the suspension seem to form clusters, are held together by fibers of sepiolite (Figs. 3 and 4 ).

Bacteria were not found in the settled phase. Only small amounts of noncrystalline precipitates were formed. These precipitates were observed by SEM and analysed by dispersive energy of X-rays.

\section{Natural-sepiolite digester}

As in the preceding material, struvite and sepiolite were also found in suspension. The natural sepiolite was more aggregated than the treated sepiolite. Thus fewer particles and bacteria were observed in suspension. No sarcines were formed and only some bacilli were detected. The observations by SEM of the sediment showed that it is similar to that of treated sepiolite. 


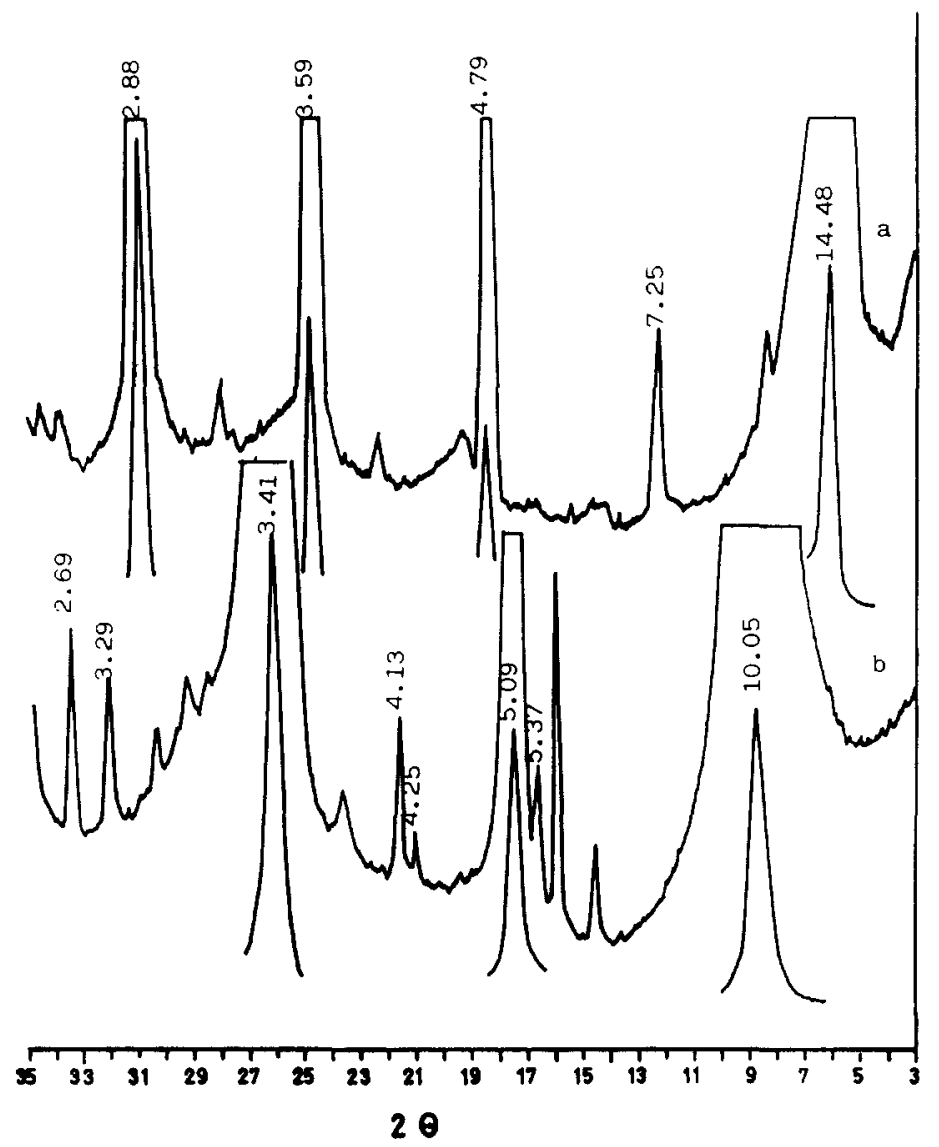

Fig. 6. a) X-ray diffraction pattern of vermiculite before the anaerobic process. b) X-ray diffraction pattern of the material in suspension of the vermiculite digester after the anaerobic process.

\section{Vermiculite digester}

The chemical analysis and the exchange capacity of the original vermiculite is shown in Table I. These data are typical of a vermiculite. After digestion the chemical analysis of the mineral by EDX indicates that its composition corresponds to a potassium-saturated vermiculite (Fig. 5). Therefore an exchange process has taken place during the digestion as confirmed by the $\mathrm{X}$-ray diffractograms. Before the treatment the XRD peaks at $14.48 \AA, 7.25 \AA, 4.79 \AA$ etc. indicated the presence of Mg-vermiculite (Justo, 1984) (Fig. 6a), whereas after the treatment they had changed to $10.05 \AA, 5.09 \AA, 3.14 \AA$ etc. (Fig. $6 \mathrm{~b}$ ). These spacings are characteristic of vermiculite containing $\mathrm{K}$ in the interlayer space.

The change of the $\mathrm{d}_{001}$ diffraction from $14.48 \AA$ to $10.05 \AA$ indicates the ex- 


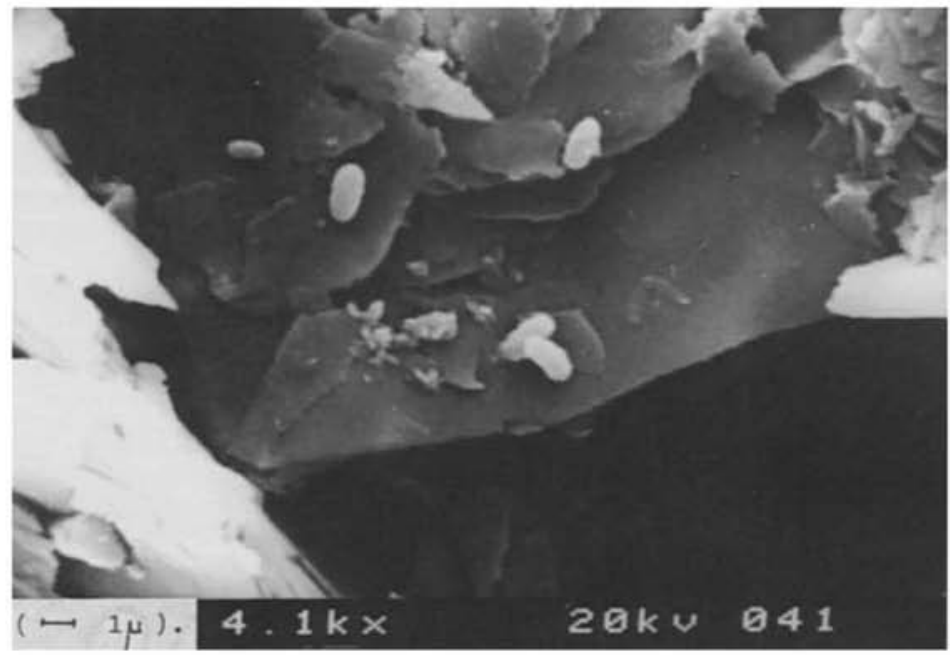

Fig. 7. Scanning electron micrograph of the material in suspension, after the anaerobic process, from the reactor using vermiculite as support (bacilli and vermiculite surfaces).

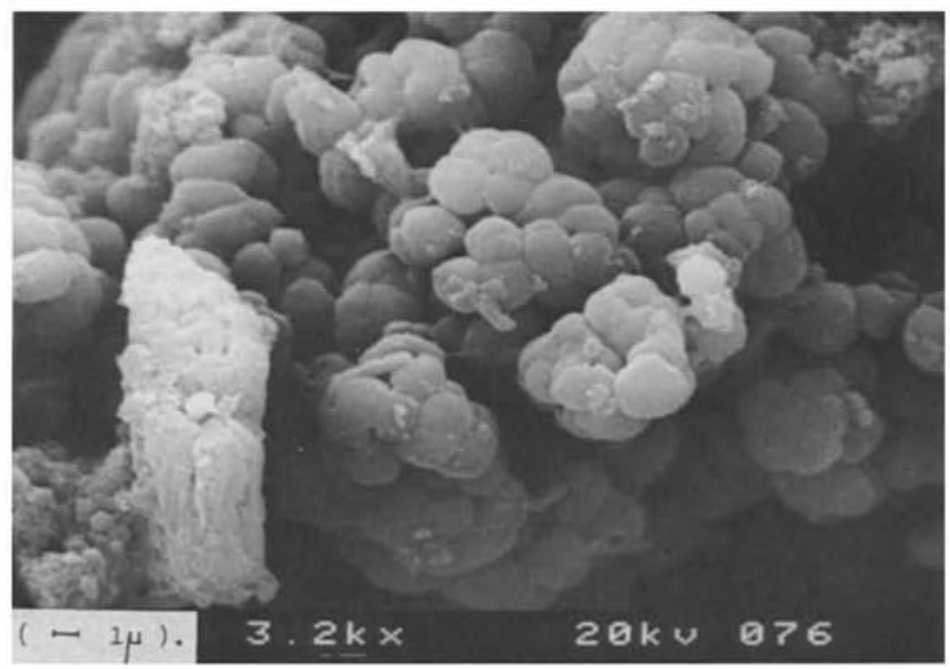

Fig. 8. Scanning electron micrograph of the material in suspension, after the process, from the reactor using bentonite as support (Methanosarcina and the mineral).

change of $\mathrm{Mg}$ ions by $\mathrm{K}$ ions from the medium. The $\mathrm{X}$-ray diffraction study also shows the presence of struvite $(5.60 \AA, 5.37 \AA, 4.25 \AA, 4.13 \AA, 3.29 \AA, 2.69 \AA$ etc.).

A low proportion of bacteria and only some bacilli were found, as shown in Fig. 7. 


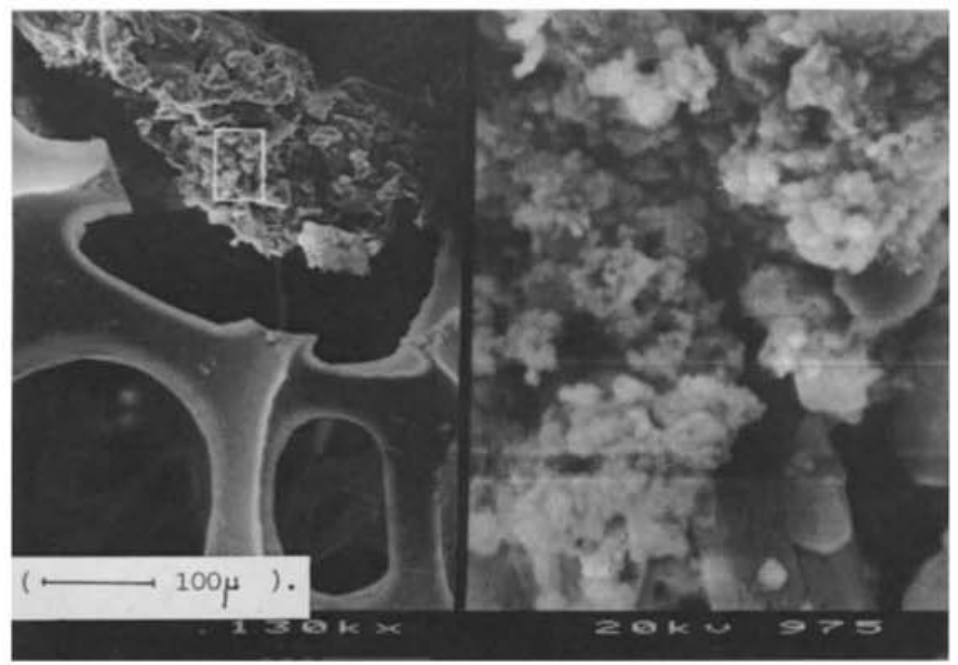

Fig. 9. Scanning electron micrograph of the expanded polyurethane after the anaerobic process (different salt precipitates and bacteria).

\section{TABLE II}

Estimation of gas production and sedimentation rate of reactors containing cultures for methanobacteria (HRT $=$ hydraulic retention time)

\begin{tabular}{|c|c|c|c|c|c|c|c|}
\hline HAc $(\mathrm{g} /$ day $)$ & \multicolumn{7}{|c|}{ Gas production ( $1 /$ day) } \\
\hline HRT & Blank & $\begin{array}{l}\text { Treated } \\
\text { Sepiolite }\end{array}$ & $\begin{array}{l}\text { Natural } \\
\text { Sepiolite }\end{array}$ & $\begin{array}{l}\text { Vermi- } \\
\text { culite }\end{array}$ & $\begin{array}{l}\text { Montmo- } \\
\text { rillonite }\end{array}$ & $\begin{array}{l}\text { Polyure- } \\
\text { thane }\end{array}$ & PVC \\
\hline & 0.110 & 0.132 & 0.115 & 0.160 & 0.125 & 0.125 & 0.120 \\
\hline & 0.136 & 0.174 & 0.145 & 0.150 & 0.165 & 0.168 & 0.160 \\
\hline & 0.142 & 0.232 & $0.1 \%$ & 0.169 & 0.190 & 0.195 & 0.187 \\
\hline & \multicolumn{7}{|c|}{ Sedimentation rate } \\
\hline & +++ & +++ & ++ & + & t+ & +++ & ++ \\
\hline
\end{tabular}


In the settled phase struvite and calcium carbonate, precipitated on the mineral surfaces are found, but no bacteria are present.

\section{Montmorillonite digester}

The concentration of this montmorillonite mineral in the suspension after the digestion process was rather low as shown by SEM and XRD.

The analysis by SEM shows a higher proportion of Methanosarcina in the suspension, as in sepiolite, but they were not attached to the mineral, as shown in Fig. 8.

In the settled phase studied by SEM bacteria were not found and struvite and noncrystalline precipitates were present. These precipitates were observed by SEM and analysed by dispersive energy of X-rays.

\section{Expanded polyurethane digester}

In the samples of the suspension of this reactor, expanded polyurethane is not present, but Methanosarcina, bacilli and cocci were found. Only struvite was detected by XRD.

In the settled fragments some bacteria and various precipitates in the pores of the material are present (Fig. 9).

\section{PVC digester}

Particles of PVC were not found in the suspension. Methanogenic bacteria (Methanosarcina) and some bacilli and struvite were found. No bacteria were found in the sediment and the PVC surface was covered with calcium carbonate after the digestion process.

Table II shows gas production and sedimentation rates of the reactors. The lowest gas production occurred in the blank. The highest gas production is that of treated sepiolite followed by expanded polyurethane and PVC. Sepiolite resulted in the highest sedimentation rate.

\section{DISCUSSION}

The experimental results suggest that the bacteria grow most rapidly when suspended treated sepiolite is the support and that only in this case the bacterial clusters are covered by the mineral. Also with this support the supernatant clears in a short time after stirring. This behaviour is very important from the industrial point of view as it makes the separation of the digested effluent easier and prevent the loss of biomass. Natural sepiolite has a different behaviour possibly because in this case the mineral is constituted by stacks of fibers which are more difficult to disperse. In contrast to the other supports, a large 
amount of finely divided mineral from treated sepiolite becomes dispersed during stirring, consequently, the specific surface of the support in this phase should be much larger than the original value which could be the reason for the large growth of bacteria.

The attraction between bacteria and sepiolite fibers could be due to specific adsorption of bacteria on the clay mineral or to some compounds or elements that bacteria need for their development either present in the mineral or in the solution. Bacteria cannot enter the channels of sepiolite due to their size. Huysman et al. (1983) believe that sepiolite has many crevices of bacteria size in its surface, but we have not observed any crevices of that size by SEM. Moreover, in the larger, deposited fragments where these crevices are possible the bacteria are produced in much lower quantity than in suspension. According to our evidence, however, the bacteria are fixed with the needles of this mineral and are not independent as is the case with the other supports. These authors also suggest that specific surface is of secondary importance in view of the poor results obtained with granulated activated carbon. However, they do not take into account that the surface of clay minerals are very different from the carbon surface and that they are not comparable. Chemical composition and release of nutrients from the minerals and their interaction with the clay surface also may play an important role.

Magnesium cations may play an important role in the anaerobic digestion process. For example, as vermiculite in suspension exchanges $\mathrm{Mg}$ by other cations in solution, this $\mathrm{Mg}$ release could explain that the reactor containing vermiculite as support has the highest gas production at the beginning of the process (during the cation exchange of magnesium by potassium), but the amount decreases after this initial stage. In contrast, sepiolite shows high gas production during the whole experiment, which agrees with its ability to release Mg continuously. The large amount of ammonium magnesium phosphate formed in digesters containing sepiolite and vermiculite, in contrast with the low proportion of this salt in digesters loaded with materials with low contents in magnesium (or magnesium-free) agree with the fact that magnesium is released from the structure of sepiolite and vermiculite. This feature has also been checked using magnesium-free cultures in digesters containing sepiolite.

It could be thought that the interlamellar space of vermiculite may play an important role in these processes, because after potassium saturation the interlayer space collapses and the gas production decreases. However, if it were so, in the case of montmorillonite (with a more accessible interlamellar space than that of vermiculite), the initial gas production should be higher than that found with vermiculite. The observations contradict this hypothesis.

The exchange capacity of minerals does not appear to influence the growth of bacteria because minerals with larger CEC (e.g. montmorillonite, 100 meq./ $100 \mathrm{~g}$ ) than sepiolites (10 meq. $/ 100 \mathrm{~g}$ ) do not show increased gas production.

The growth of methanobacteria and consequently the gas production in- 
crease when the clay minerals pass into suspension, as can be deduced from the different behaviour of natural and treated sepiolite. These results suggest the convenience of using clay suspensions and fluidised beds, which could perhaps improve the results obtained with montmorillonite, which can be easily brought into suspension.

A large surface area and a capacity to bind bacteria to the surface in intimate mineral contact are important for the growth of bacteria.

\section{ACKNOWLEDGEMENTS}

The authors gratefully acknowledge the invaluable collaboration provided by Dr. Fiestas and wish to thank Dr. Madrid for reading the manuscript and giving valuable suggestions, and E. Gomez for realizing the Electronic Microscopy photos.

We are grateful to the Comisión Asesora de Investigación Científica y Técnica, Spain, for financial support of this work through Project No. 603-502.

\section{REFERENCES}

Bennet, H., Eardley, R.P., Hawley, W.G. and Thwaites, I., 1962. Routine control analysis of highsilica and aluminosilicate materials. Trans. Br. Ceram. Soc., 61: 636-666.

Carretero, M.I., Maqueda, C., Pérez Rodríguez, J.L. and Justo, A., 1986. Estudio de fosfatos precipitados en digestores anaeróbicos. Bol. Soc. Esp. Min., 9: 161-167.

Ellwood, D.C., Keevilc, W., Marsh, P.D., Brown, C.M. and Wardell, J.N., 1982. Surface-associated growth. Phil. Trans. R. Soc. London, Ser. B., 297: 517-432.

Geeta, G.S., Raghavendra, S. and Reddy, R., 1986. Agricultural Waster, 17: 153-156.

Harvey, M., Forsberg, C.W., Beveridge, T.J., Pos, J. and Ogilvie, J.R., 1984. Methanogenic activity and extrastructural characteristics of the microbial biofilm on a needle punched polyester support. Appl. Environ. Microbiol., 48(3): 633-638.

Hattori, T. and Hattori, R., 1976. The physical environment in soil microbiology: an attempt to extend principles of microbiology to soil microorganism. Critical Rev. Microbiol., 4: 423-461.

Henze, M. and Harremöes, P., 1983. Anaerobic treatment of waste water in fixed film reactors. A literature review. Water Sci. Technol., 15: 1-101.

Hoban, D.J. and Van der Berg, L., 1979. Effect of iron on conversion of acetic acid to methane during methanogenic fermentation. J. Appl. Bacteriol., 47: 153-159.

Huysman, P., Van Meenen, P., Van Assche, P. and Verstraete, W., 1983. Factors affecting the colonization of non porous packing materials in models upflow methane reactors. Biotechnol. Lett., 5(9): 643-648.

Justo, A., 1984. Estudio fisicoquímico de vermiculitas de Analucía y Badajoz. Tesis Doctoral. Universidad de Sevilla.

Lequerica, J.L. and Toldrá, F., 1986. Examen microscópico de microorganismos presentes en reactores metanogénicos de lecho fluidizado. Rev. Agroquím. Technol. Aliment., 26(1): 90-100. Murray, W.D. and Van der Berg, L., 1981. Effect of support material on the development of microbial fixed film converting acetic acid to methane. J. Appl. Bacteriol., 51: 257-265.

Salkinoja-Salonen, M., Kakulinen, R., Valo, R. and Apajalahti, J., 1983. Biodegradation of recal- 
citrant organochlorine compounds in fixed film reactors. Anaerobic treatment of wastewater in fixed film reactors. Water. Sci. Technol, 15: 309-319.

Schoberth, S., 1979. Interspecies $\mathrm{H}_{2}$-transfer in der Methangärung: Desulfovibrio gigas und Methanobacterium bryantii. In: H. Relweg (Editor), 4th Symp. Technol. Mikrobiologie, Berlin. Verlag VLSF, Berlin, pp. 353-362.

Slater, J.H., 1978. The role of microbial communities in the natural environment. 138-152. In: K.W.A. Chater and H.J. Somerville (Editors), The Oil Industry and Microbial Ecosystems. Heyden, London, pp. 138-152.

Stotzky, G., 1966. Influence of clay minerals on microorganisms, II. Effect of various clay species, homoionic clays, and other particles on bacteria. Can. J. Microbiol., 12: 831-848.

Stotzky, G. and Rem, L.T., 1966. Influence of clay minerals on microorganisms. I. Montmorillonite and kaolinite on bacteria. Can. J. Microbiol., 12: 547-563.

Van der Berg, L. and Kennedy, K.J., 1981. Support materials for stationary fixed film ractors for high-rate methanogenic fermentations. Biotech. Lett., 3, (4): 165-170. 